\title{
Enzyme-Catalyzed Synthesis and Characterization of Octyl Dihydroxystearate from Palm-Based Dihydroxystearic Acid
}

\author{
Roila AwAng ${ }^{*}$, Mahiran BASri ${ }^{2}$, Salmiah AHMAd $^{1}$ and \\ Abu Bakar SAlleH ${ }^{2}$ \\ ${ }^{I}$ Advanced Oleochemical Technology Centre, Malaysian Palm Oil Board \\ (43650 Bandar Baru Bangi Selangor, MALAYSIA) \\ ${ }^{2}$ Enzyme and Microbial Technology Research, Fakulti Sains \& Pengajian Alam Sekitar, Universiti Putra Malaysia \\ (43400 Serdang, Selangor, MALAYSIA)
}

Edited by D. Kitamoto, AIST, Tsukuba, and accepted September 10, 2002 (received for review July 19, 2002)

\begin{abstract}
Octyl dihydroxystearate was synthesized enzymatically to overcome the problems associated with chemical processes such as high energy costs and degradation of ester. Immobilized enzyme, Lipozyme IM was employed as catalyst in the esterification reaction between dihydroxystearic acid (DHSA) and 1-octanol. The product obtained was characterized by chromatographic and spectroscopic methods (thin-layer chromatography, gas chromatography, fourier transform infrared, nuclear magnetic resonance spectroscopy) as well as wet chemistry. The crude product has a melting point of $59.0^{\circ} \mathrm{C}$, saponification value of 140.5 $\mathrm{mgKOH} / \mathrm{g}$, hydroxyl value of $223.9 \mathrm{mgKOH} / \mathrm{g}$ and acid value of $7.9 \mathrm{mgKOH} / \mathrm{g}$. The yield was about $95 \%$ with respect to the amount of DHSA used. The product obtained was found to contain octyl dihydroxystearate, octyl palmitate and octyl stearate. This compound was found to be nonirritating.
\end{abstract}

Key words: octyl dihydroxystearate, dihydroxystearic acid, irritancy, characterization

\section{Introduction}

Wax esters are esters of long chain fatty acids and long chain fatty alcohols. They have a wide range of uses as lubricants, plasticizers, coating materials in the medical and food industries, and as raw materials in cosmetics and other chemical industries (1). Hydroxy stearates are usually known in the form of wax esters (2). Hydroxy acid esters have a variety of uses; such as plastisizers, mold release agent, cosmetics (hair products, lipsticks and lotion) and chemical intermediates (3). Sulphonated wax esters of ricinoleic acid are promising surface-active compound (4). Currently wax esters are produced by reacting a fatty acid and an alco- hol at high temperatures in the presence of tin, titanium, or sulfuric acid catalyst. This high-temperature process can lead to degradation of the esters and undesired side reactions; additionally the resulting energy cost is high (5).

Taking these aspects into consideration, biotechnological methods, such as bioconversion, become more advantages. Lipase-catalyzed esterification is possible at moderate temperature at neutral $\mathrm{pH}$ under normal pressure in simple reaction vessels. Recently, lipases with organic solvent-based media have been employed for the synthesis of hydroxy acid esters. Goshray and Bhattacharyya (4) and Mukesh et al., (6) have produced ricinoleic acid wax ester from Rhizomucor meihei

\footnotetext{
*Correspondence to: Roila AwANG, Advanced Oleochemical Technology Centre, Lot 9 \& 11, Jalan P/14, Section 10, 43650 Bandar Baru Bangi, Selangor, MALAYSIA

E-mail: roila@mpob.gov.my
} 
lipase-catalyzed esterification of ricinoleic acid or alcoholysis of castor oil at high yield. While Lang et al., (7) synthesized wax esters of $(S)$-17-hydroxystearic acid and $(R)$-3-hydroxydecanoic acid with various lipases. Several hydroxy acid wax esters produced in these investigation were found to be useful surfactant $(3,4,6,7)$. Previous study had shown that lipase-catalyzed esterification of DHSA and monohydric alcohol could be achieved with high yield (8). However, there is no complete data on the characterization of octyl dihydroxystearate. Therefore, in this paper, we report the synthesis and characterization of octyl dihydroxystearate via direct esterification of dihydroxystearic acid and 1-octanol using Lipozyme IM as catalyst.

\section{Materials and Methods}

\subsection{Materials}

DHSA was prepared in the laboratory (9). 1-Octanol (purity, 99\%) was purchased from Sigma Chemical Co. (St. Louis, MO). Lipozyme IM (lipase from $R$. meihei was donated by Novozyme A/S (Bagsvaerd, Denmark). $\mathrm{N}, \mathrm{O}$-Bis-trimethylsilyl acetamide (purity, $>98 \%$ ) was from Merck (Darmstadt, Germany). All other reagents were of analytical grade and used as received.

\section{$2 \cdot 2$ Octyl Dihydroxystearate Synthesis}

In general, 1-octanol was used at a molar excess of 2:1 in $250-\mathrm{mL}$ stoppered Erlenmeyer flask in order to increase solubility of DHSA in reaction mixture. The bioconversion was started by addition of $15 \%(\mathrm{w} / \mathrm{w})$ Lipozyme IM and the reaction mixture consisted of DHSA $(0.1 \mathrm{~mol})$ and 1-octanol $(0.2 \mathrm{~mol})$ was incubated at $50^{\circ} \mathrm{C}$ for $3 \mathrm{~h}$ with shaking speed of $200 \mathrm{rpm}$. Hexane was used as a solvent. For the purpose of further analysis, the reaction was terminated by separating the enzyme from the mixture by means of filtration using a filter paper. The solvent was removed by rotary evaporation. Details of product isolation and purification were described in our previous study (8).

\subsection{Thin-Layer Chromatography (TLC)}

Sample of crude product was dissolved in appropriate organic solvent and separated on a layer of silica gel with hexane/ethyl acetate/acetic acid (20:80:1, $\mathrm{vol} / \mathrm{vol} / \mathrm{vol}$ ) as the developing solvent. Visualization of the chromatogram was carried out by charring at $140^{\circ} \mathrm{C}$ after the plate was sprayed with sulfuric acid solution
$(50 \%)$.

\subsection{Gas Chromatography (GC) of Tri- methylsilyl (TMS) Derivatives of Octyl Dihydroxystearate}

GC analysis was carried out using a Hewlett-Packard HP-6860A Plus gas chromatograph (Palo Alto, CA). The TMS derivatives of octyl dihydroxystearate was separated on a nonpolar column, HP-5 (HewlettPackard, $30 \mathrm{~m} \times 0.25 \mathrm{~mm} \times 0.25(\mu \mathrm{m})$ with helium as the carrier gas. The oven was programmed to hold at $150^{\circ} \mathrm{C}$ for $1 \mathrm{~min}$, followed by ramping from $150^{\circ} \mathrm{C}$ to $290^{\circ} \mathrm{C}$ at a rate of $10^{\circ} \mathrm{C} / \mathrm{min}$. The final temperature was held at $290^{\circ} \mathrm{C}$ for $30 \mathrm{~min}$. The injector and flame-ionization detector were set at $300^{\circ} \mathrm{C}$.

\section{$2 \cdot 5$ GC-Mass Spectrometry (GC-MS) of TMS-Derivatives of Octyl Dihydroxy- stearate}

GC-MS of the TMS-derivatives was performed on a Perkin Elmer Instrument model Q-mass 910 mass spectrometry. The GC was equipped with a SE-52 capillary column. The carrier gas was helium at a flow rate of 1 $\mathrm{mL} / \mathrm{min}$. The column temperature was initially kept at $180^{\circ} \mathrm{C}$ for $1 \mathrm{~min}$, then programmed to $280^{\circ} \mathrm{C}$ at $10^{\circ} \mathrm{C}$ $/ \mathrm{min}$. The final temperature was held for $35 \mathrm{~min}$. Other operating conditions were; injector temperature of $280^{\circ} \mathrm{C}$, auxiliary temperature $220^{\circ} \mathrm{C}$ and split ratio was 100:1.

\subsection{Preparation of TMS-Derivatives for GC and GC-MS Analyses}

Sample $(0.01 \mathrm{~g})$ was weighed into a vial. One $\mathrm{mL}$ of GC grade $N, N$-dimethylformamide and $N, O$-bistrimethylsilyl acetamide $(0.5 \mathrm{~mL})$ were added. The sample was mixed using vortex mixer for 15-30 sec and warmed at $60^{\circ} \mathrm{C}$ for $30 \mathrm{~min}$. The sample was allowed to cool for a few minutes before injection.

\subsection{Nuclear Magnetic Resonance (NMR) Spectroscopy of Octyl Dihydroxys- tearate}

Proton NMR ( ${ }^{1} \mathrm{H}$ NMR) spectrum was obtained on a Hitachi NMR R-1200 spectrometer $(60 \mathrm{MHz})$ in deuterated chloroform $\left(\mathrm{CDCl}_{3}\right)$ with tetramethylsilane as internal standard. ${ }^{13} \mathrm{C}$ NMR spectrum was recorded on a Bruker DRX-300 (Karlsruhe, Germany) spectrometer at $300 \mathrm{MHz}$. The chemical shifts are expressed in ppm. 
Acid value, iodine value, hydroxyl value and saponification value were determined by standard procedures (AOCS official methods): acid value, Te 1a-64; iodine value, Cd 1d-92; hydroxyl value, Cd I3-60; saponification value TI 1a-64 (10). Fourier transform infrared (FTIR) spectra were recorded on a Nicolet MagnaIR550 (Nicolet, Madison, WI) spectrophotometer.

\subsection{Thermal Stability}

Thermal stability of octyl dihydroxystearate was studied using a Differential Scanning Calorimeter (DSC) (TA, Instrument, New Castle, DE). Samples of $10 \mathrm{mg}$ were weighed in ceramic measuring cup, which were closed and placed into the calorimeter. An empty cup with cap was used for reference. DSC heating curves were determined by heating at a temperature range from room temperature to $190^{\circ} \mathrm{C}$ at a heating rate of $5^{\circ} \mathrm{C} / \mathrm{min}$. The heating process was repeated 3 times.

\section{$2 \cdot 9$ Solubility Test}

Sample $(0.1 \mathrm{~g})$ was placed into a conical flask. Solvent was then added dropwise to the flask using a buret. Continuous stirring at room temperature was carried out until no undissolved particles were seen. The solution was stirred for $15 \mathrm{~min}$ before solubility was determined.

\subsection{Irritancy Test}

Dermal irritancy of octyl dihydroxystearate was conducted using The Irritection Assay System, which consists of a test kit, instrumentation, and computer software ( In Vitro International, Irvine, CA). Samples were weighed at four different concentrations- 50, 75, 100 and $125 \mathrm{mg}$-and placed into the membrane discs. Reagent and blanking buffer $(1250 \mu \mathrm{L})$ were added to a 24-well assay plate. The membrane discs that con- tained various concentrations of octyl dihydroxystearate sample were inserted into the corresponding blank and test sample wells of the plate. The assay plate was then incubated at $25^{\circ} \mathrm{C}$ for $24 \mathrm{~h}$. After this time the membrane discs were removed from the assay plate, and 250 $\mu \mathrm{L}$ of reagent plus blanking buffer was transferred into the 96-well reading plate. This plate was inserted into the MRX Microplate Reader (Dynex Technologies, Inc., Chantilly, VA).

\section{Results and Discussion}

In a typical reaction of DHSA with 1-octanol, catalyzed by Lipozyme IM, the reaction product was isolated as described in the Experimental section, to yield of octyl dihydroxystearate of $95 \%$ with respect to the amount of DHSA used.

\section{3·1 Analysis of Product}

Properties of the starting materials and the products, such as hydroxyl value, saponification value, acid value and melting point are shown in Table 1. The results showed that the acid value decreased in the conversion of the reactant to the product. This indicates the formation of ester compound. The saponification value and hydroxyl value also decreased, this may be due to the increasing of molecular weight of the product.

TLC of the product indicates the formation of new product (Fig. 1). In the FTIR spectrum, a strong O-H transmittance peak appears at $3330 \mathrm{~cm}^{-1}$, which indicates that the hydroxyl group of parent acid remains unaffected by action of the enzyme. The carboxylic carbonyl transmittance peak shifts from $1709 \mathrm{~cm}^{-1}$ to $1739 \mathrm{~cm}^{-1}$ in the product due to the change from acid to ester group. This finding was in agreement with Sil-

Table 1 Properties of DHSA, Crude Product and Purified Product ${ }^{\mathrm{a}, \mathrm{b}}$.

\begin{tabular}{lrrr}
\hline Parameter & \multicolumn{1}{c}{ DHSA $^{*}$} & Crude Product & Purified Product \\
\hline Acid Value $(\mathrm{mgKOH} / \mathrm{g})$ & $180.3 \pm 1.2$ & $7.9 \pm 0.8$ & $1.8 \pm 0.1$ \\
OHV $(\mathrm{mgKOH} / \mathrm{g})$ & $309.3 \pm 3.9$ & $223.9 \pm 4.6$ & $246.1 \pm 3.5$ \\
Sap. Value $(\mathrm{mgKOH} / \mathrm{g})$ & $178.5 \pm 1.0$ & $140.5 \pm 0.5$ & $138.5 \pm 0.7$ \\
Iodine Value $\left(\mathrm{g} \mathrm{I}_{2} / 100 \mathrm{~g}\right)$ & $1.1 \pm 0.2$ & $6.0 \pm 0.1$ & $0.3 \pm 0.1$ \\
Melting Point $\left({ }^{\circ} \mathrm{C}\right)$ & $90.6 \pm 0.9$ & $59.0 \pm 0.1$ & $69.8 \pm 0.2$ \\
\hline
\end{tabular}

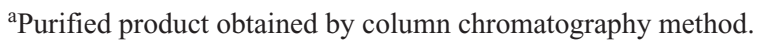

${ }^{\mathrm{b}}$ Average values determined in duplicate.

*Data from Awang et al., (16). 


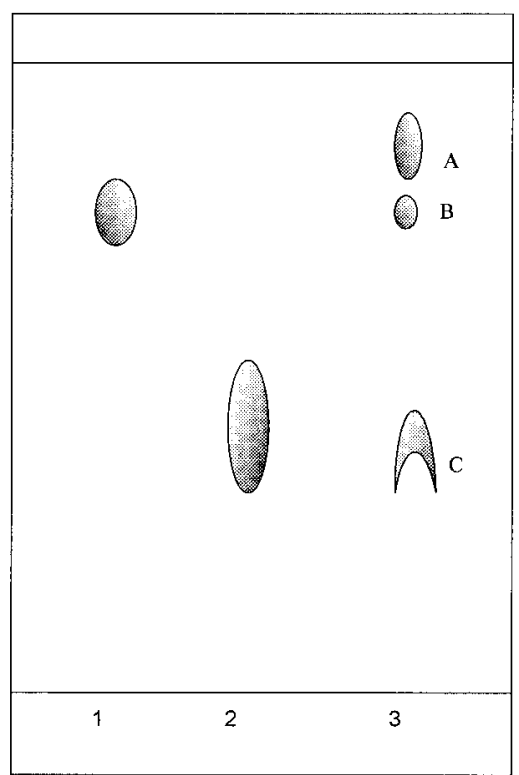

Fig. 1 Thin-layer Chromatogram of Octyl Dihydroxystearate Derived from Palm-based DHSA. Developing solvent: Hexane/ethyl acetate/ acetic acid (20:80:1, by vol). (1) 1-octanol, (2) DHSA, (3) crude product, (A) product, (B) unreacted 1-octanol and $(C)$ unreacted DHSA vertein et al., (11) who proposed that ester compound have a characteristically strong absorption band arising from $\mathrm{C}=\mathrm{O}$ stretching at $1730-1740 \mathrm{~cm}^{-1}$.

\section{$3 \cdot 2$ GC Analysis}

GC analysis of octyl dihydroxystearate was compared with the standard (data not shown). As shown in Fig. 2, the chromatogram of octyl dihydroxystearate after conversion to TMS derivatives revealed the presence of other compounds along with octyl dihydroxystearate. The major peak was appeared at retention time (Rt) 19.12 min assigned to octyl dihydroxystearate. Unreacted DHSA and 1-octanol appeared at Rt 14.33 min and $2.89 \mathrm{~min}$, respectively. While octyl palmitate and octyl stearate at Rt $14.55 \mathrm{~min}$ and $16.09 \mathrm{~min}$. These are possibly due to the trace impurities present in DHSA. The oleic acid used as starting materials for production of DHSA is of $75 \%$ purity. It also contained saturated fatty acid at various chain length $\left(\mathrm{C}_{12}, \mathrm{C}_{14}\right.$, $\mathrm{C}_{16}, \mathrm{C}_{18}$ and $\left.\mathrm{C}_{20}\right)(12)$.

\section{3·3 GC-Mass Spectrometry Analysis}

Scheme 1 shows a general MS fragmentation pattern of octyl dihydroxystearate. The MS data for octyl dihydroxystearate showed that the major ions at $\mathrm{m} / \mathrm{z} 358$

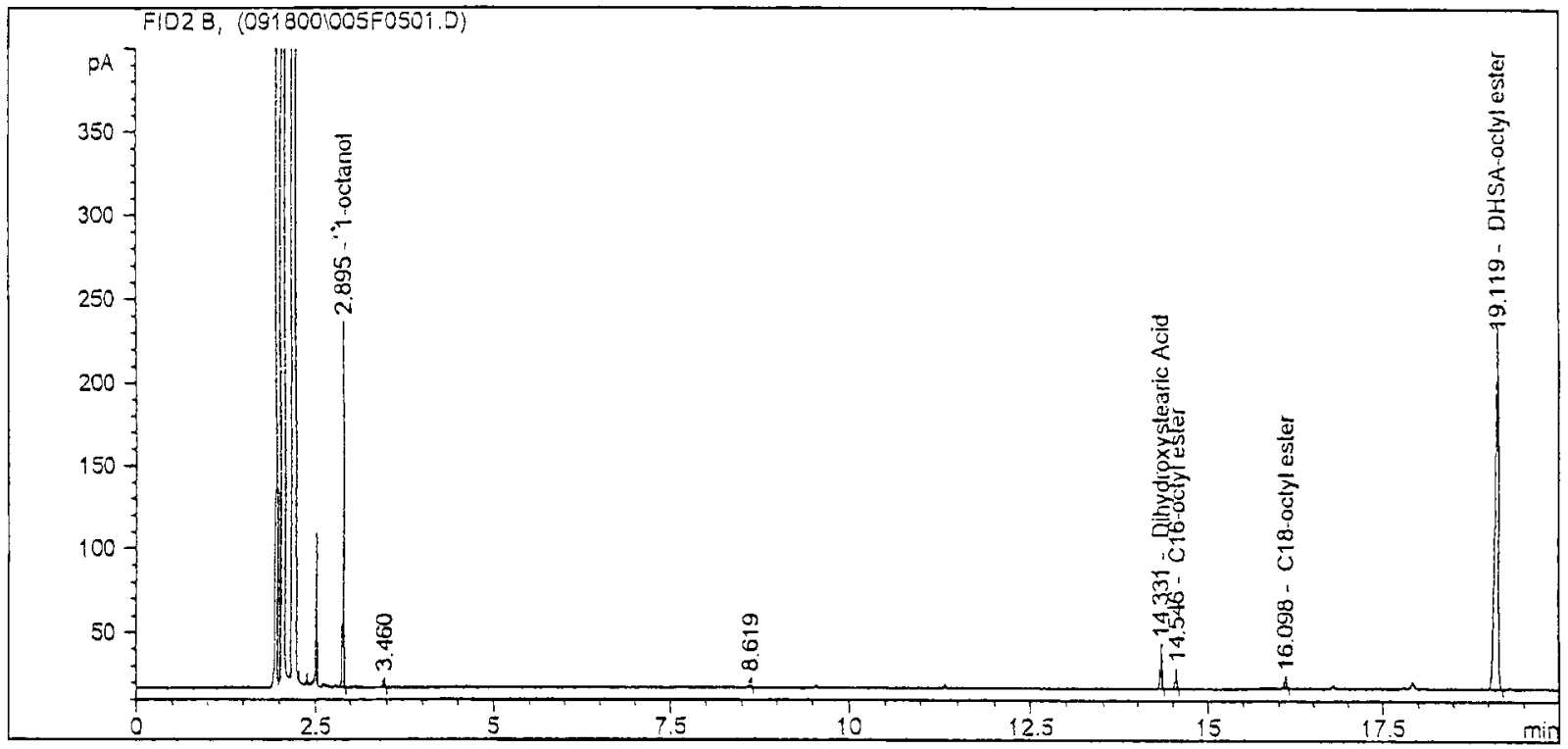

Fig. 2 Gas Chromatographic Separation of the Components of Octyl Dihydroxystearate Prepared from Palm Based DHSA after Derivatization with $\mathrm{N}, \mathrm{O}$-bistrimethylsilyl Acetamide. Column: HP-5 [(5\%-phenyl)-methylpolysiloxane], 0.25 $\mathrm{mm} \times 30 \mathrm{~m} \times 0.25 \mu \mathrm{m}$. Oven: $150^{\circ} \mathrm{C}$ for $1 \mathrm{~min}, 150-290^{\circ} \mathrm{C}$ at $10^{\circ} \mathrm{C} / \mathrm{min}, 290^{\circ} \mathrm{C}$ for $30 \mathrm{~min}$. 


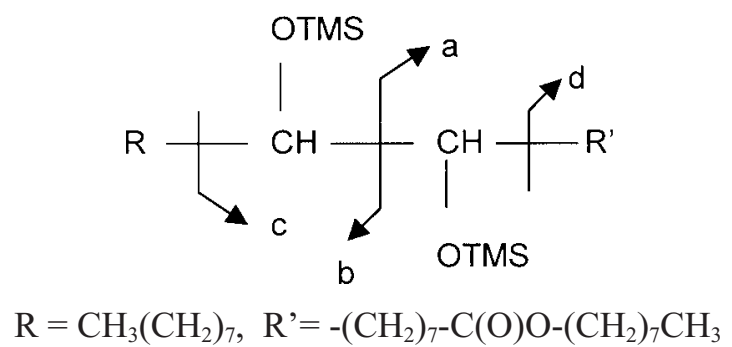

Scheme 1 General Fragmentation of Octyl Dihydroxystearate.

and 215 arise from path a and b cleavage (Fig. 3) whereas $\mathrm{m} / \mathrm{z} 431$ is expected rearrangement ion resulting from path c cleavage and TMS migration with lost of $\mathrm{CHO}(\mathrm{m} / \mathrm{z} 459-29)$. The fragmentation at $\mathrm{m} / \mathrm{z} 319$ confirms path d cleavage. Similar fragmentation pattern was reported by Carlson et al., (13) for methyl 13,14dihydroxydocosanoate.

\subsection{NMR Analysis}

Octyl dihydroxystearate was also subjected to ${ }^{1} \mathrm{H}$ NMR and ${ }^{13} \mathrm{C}$ NMR: ${ }^{1} \mathrm{H}$ NMR of octyl dihydroxy stearate in $\mathrm{CDCl}_{3}$ exhibited the following peaks: 4.07 ppm $(\mathrm{OH}), 3.96 \mathrm{ppm}(\mathrm{CHOH}), 2.73 \mathrm{ppm}\left(\mathrm{CH}_{2}-\mathrm{CH}(\mathrm{O})\right)$, 1.28-1.80 ppm $\left(\mathrm{CH}_{2}\right)$ and $0.94 \mathrm{ppm}\left(\mathrm{CH}_{3}\right) \cdot{ }^{13} \mathrm{C} \mathrm{NMR}$ confirmed the presence of the following group: carbonyl at $174.08 \mathrm{ppm}$, two hydroxyls carbon at 74.47 ppm and $74.66 \mathrm{ppm},-\mathrm{O}-\mathrm{CH}_{2}$ at $64.48 \mathrm{ppm},-\mathrm{CH}_{2}$ - carbon cover the range from 24.96 to $34.37 \mathrm{ppm}$, two $\mathrm{CH}_{2} \mathrm{CH}_{3}$ groups at 22.68 and $22.65 \mathrm{ppm}$ and methyl carbon at $14.12 \mathrm{ppm}(8)$.

\subsection{Thermal Stability}

Thermal stability of crude and purified octyl dihydroxystearate was determined based on melting point by using DSC. The DSC melting thermograms of crude octyl dihydroxystearate revealed a variation in melting point from $63.7^{\circ} \mathrm{C}$ to $66.8^{\circ} \mathrm{C}$ after being heated at RT to $190^{\circ} \mathrm{C}$ for 3 cycles (Fig. 4). However, there was no variation in the melting point for purified product (Fig. 5).

\subsection{Solubility Properties}

As shown in Fig. 6 crude octyl dihydroxystearate is more soluble in alcohol compared to purified product. This observation may be due to the presence of excess octanol in crude product, where octanol was removed during purification process. The solubility of this compound is increased by increasing alcohol chain-length from $\mathrm{C}_{1}$ to $\mathrm{C}_{3}$ and slightly decreased or constant at higher chain-length. This phenomenon may be attributed to increase in viscosity of solvent.

According to Kim (14) the solubility of a substrate in a nonaqueous system depends primarily on the melting point and heat of fusion of the solute and on those characteristic of the solvent that determine the degree of mutual affinity of solvent and solute molecules.

\section{$3 \cdot 7 \quad$ Irritancy Properties}

Table 2 shows the dermal irritancy potential of octyl dihydroxystearate from various ratio of 1-octanol. All samples were predicted to be nonirritating with Human Irritancy Equivalent (HIE) score below 0.90. This results showed the skin compatibility of octyl dihydroxystearate. Therefore, it has potential for use in cosmetics

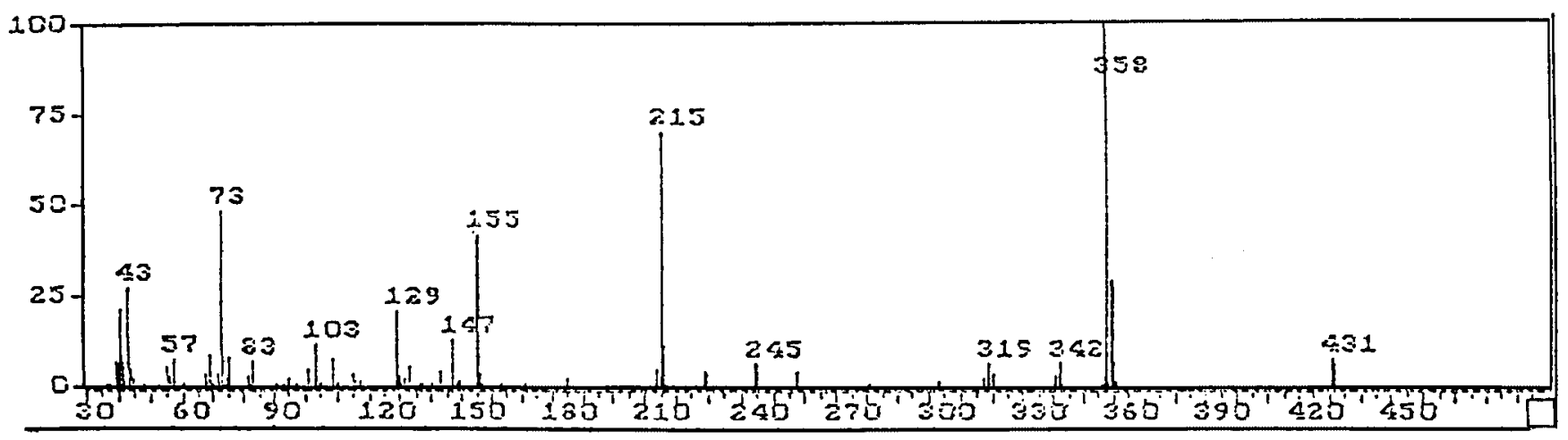

Fig. 3 Electron Impact GC-mass Spectrometry Fragmentation of Octyl Dihydroxystearate Derived from Palm Based DHSA after Derivatization with $N, O$-bistrimethylsilyl Acetamide. 


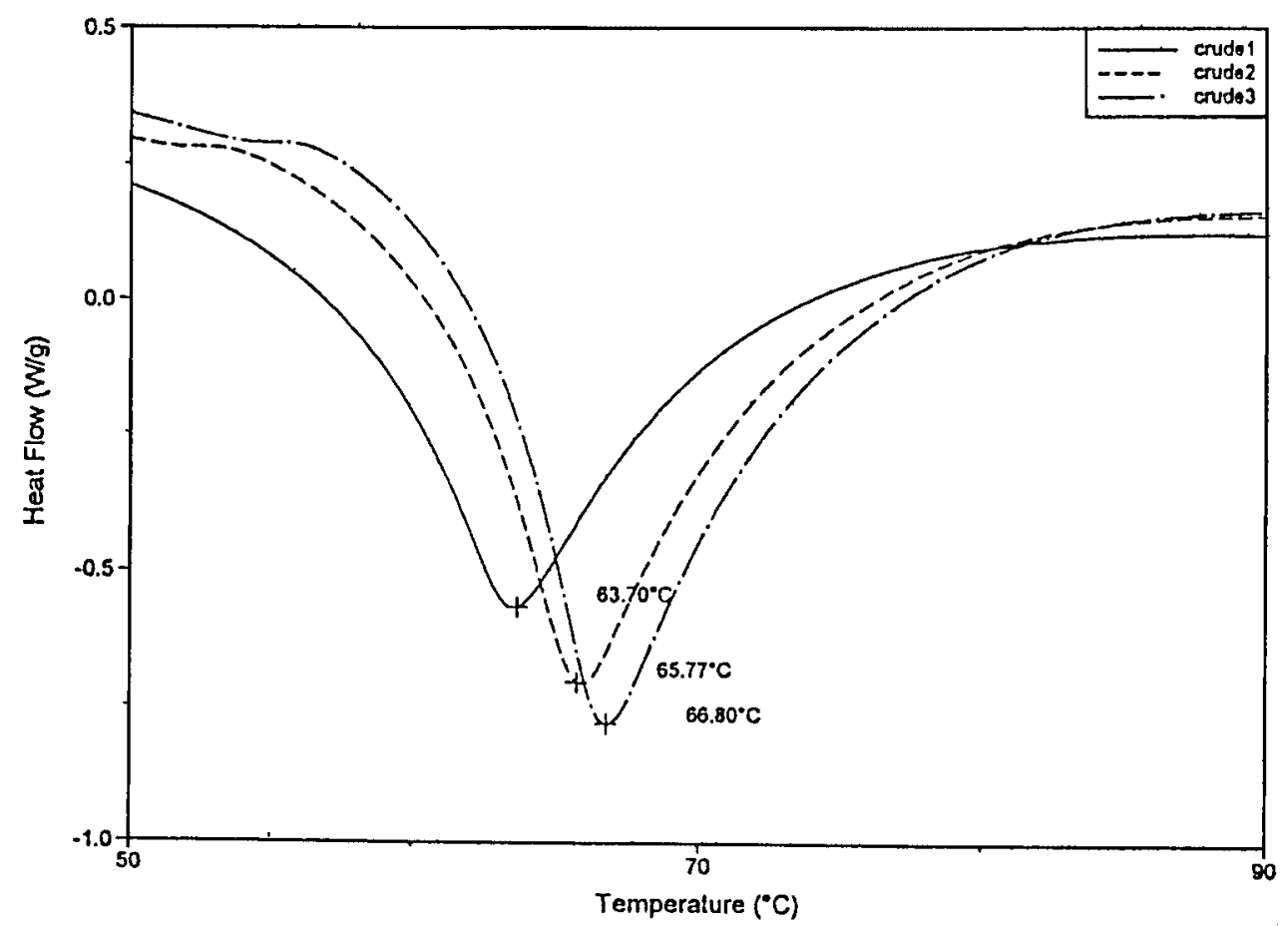

Fig. 4 Differential Scanning Calorimetry Melting Thermogram of Crude Octyl Dihydroxystearate. Sample was heated at room temperature to $190^{\circ} \mathrm{C}$ at a rate of $5^{\circ} \mathrm{C} /$ $\min$ for 3 cycles.

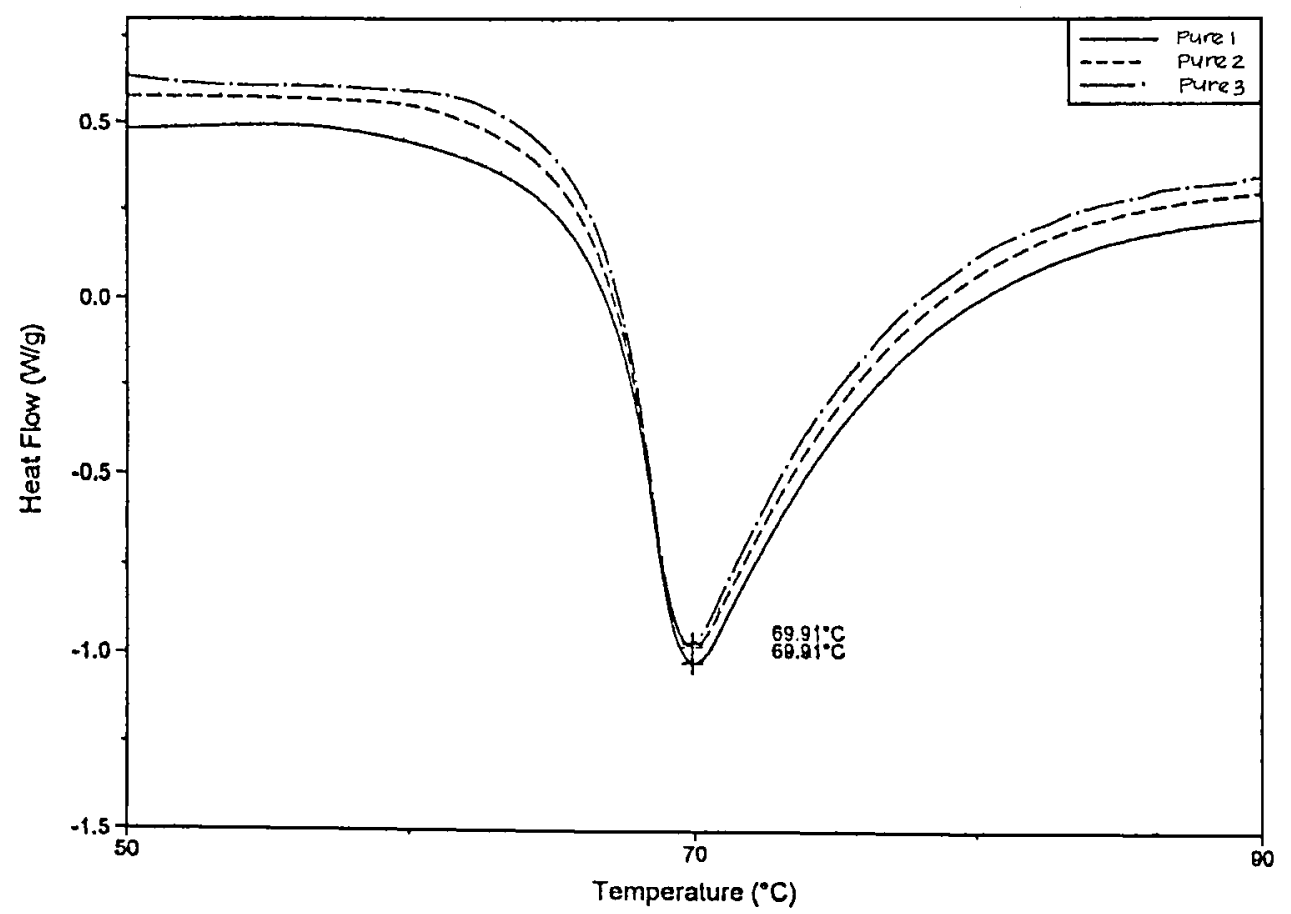

Fig. 5 Differential Scanning Calorimetry Melting Thermogram of Purified Octyl Dihydroxystearate. Sample was heated at room temperature to $190^{\circ} \mathrm{C}$ at a rate of $5^{\circ} \mathrm{C} /$ min for 3 cycles. 


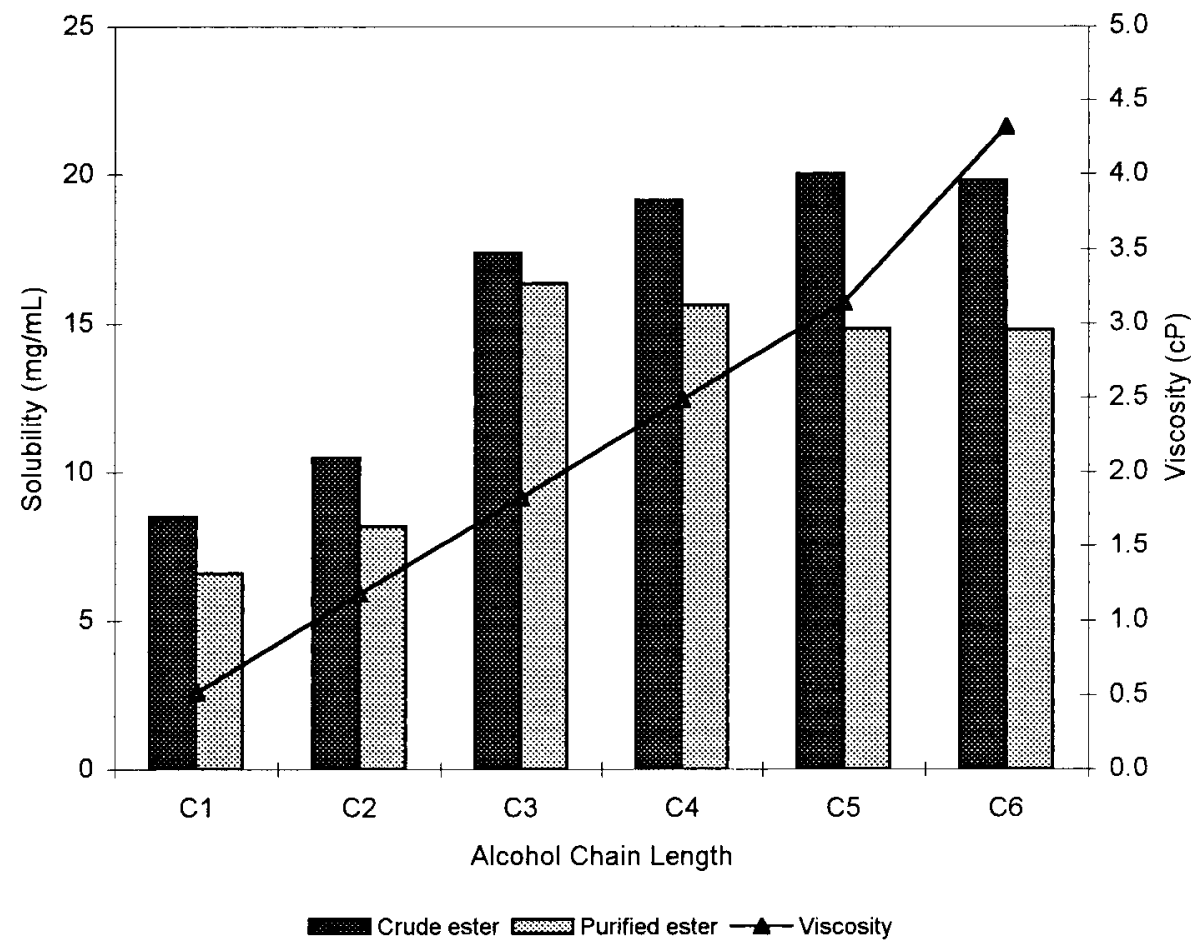

Fig. 6 Solubility of Crude and Purified Octyl Dihydroxystearate in Alcohol of Various Chain Length. Solubility test was carried out as described in Materials and Methods Section. Viscosity was measured at $25^{\circ} \mathrm{C}$ using $\mathrm{CP} 40$ spindle at $2.5 \mathrm{rpm}$.

Table 2 Irritancy Test of Octyl Dihydroxystearate Produced at Various Mole Ratio of Substrate ${ }^{\mathrm{a}, \mathrm{b}}$.

\begin{tabular}{ccccc}
\hline Dose, $\mathrm{mg}$ & \multicolumn{2}{c}{ Irritancy score (DHSA: 1-Octanol) } & Irritancy Classification \\
\cline { 2 - 4 } & $1.0: 1.0$ & $1.0: 1.5$ & $1.0: 2.0$ & \\
\hline 50 & 0.28 & 0.22 & 0.00 & Nonirritant \\
75 & 0.25 & 0.28 & 0.05 & Nonirritant \\
100 & 0.37 & 0.29 & 0.16 & Nonirritant \\
125 & 0.60 & 0.33 & 0.25 & Nonirritant \\
\hline
\end{tabular}

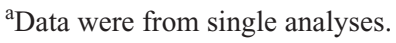

${ }^{b}$ Data were obtained using The Irritection Assay System (In Vitro International, Irvine,

CA) as described in the Materials and Methods section of the test.

and personal care products. It was reported that the Dermal Irritection Assay Method could be employed to evaluate multiple samples at varying concentrations readily. Thus the test serves as a useful screening tool that facilitates all stages of raw material selection, formulation development, and final product selection (15).

\section{Conclusion}

Octyl dihydroxystearate was synthesized by Lipozyme IM at mild condition with high percentage of conversion. This compound was found to be nonirritating. 


\section{Acknowledgement}

The authors would like to thank the Director General of MPOB for permission to publish this paper.

\section{References}

1. M.L. HALBERG, D. WANG and M. HARROD, Enzymatic Synthesis of Wax Ester from Rapeseed Fatty Methyl Esters and Fatty Alcohol, J. Am. Oil Chem. Soc., Vol. 76, 183-187 (1999).

2. M. GOSH and D.K. BHATTACHARYYA, Lipase-Catalyzed Synthesis of Hydroxystearated and Their Properties, J. Am. Oil Chem. Soc., Vol. 75, 1057-1059 (1998).

3. D.G. HAYES and R. KLEIMAN, Lipase-Catalyzed Synthesis of Lesquerolic Acid Wax and Diol Esters and Their Properties, $J$. Am. Oil Chem. Soc., Vol. 73, 1385-1392 (1996).

4. S. GHOSHRAY and D.K. BHATTACHARYYA, Enzymatic Preparation of Ricinoleic Acid Esters of Long-Chain Monohydric Alcohols and Properties of the Esters, J. Am. Oil Chem. Soc., Vol. 69, 85-88 (1992).

5. W. LOKOTSCH, S. LANG, D. MOBIUS and F. WAGNER, Biocatalytical Synthesis and Monolayer Studies of Multiple Hydroxylated Wax Esters, J. Am. Oil Chem. Soc., Vol. 73, 14591464 (1996).

6. D. MUKESH, R.S. IYER, J.S. WAGH, A.A. MIKASHI, A.A. BANERJI, R.V. NEWADKAR and H.S. BEVINAKATTI, Lipase Catalyzed Transesterification of Castor Oil, Biotechnol. Lett., Vol. 15, 251-256 (1996).
7. S. LANG, R. MULTZSCH, A. PASSERI, A. SCHMEICHEL, B. STEFFEN, F. WAGNER, D. HAMANN and H.K. CAMMENGA, Unusual Wax Esters and Glycolipids: Biocatalytical Formation and Physico-Chemical Characterization, Acta Biotechnol., Vol. 11, 379-386 (1996).

8. R. AWANG, M. BASRI, S. AHMAD and A.B. SALLEH, Enzymatic Esterification of Dihydroxystearic Acid, J. Am. Oil Chem. Soc., Vol. 77, 609-612 (2000).

9. R. AWANG, S. AHMAD and Y.B. KANG, Malaysian Patent PI 9, 804,456 (1998).

10. Official Methods and Recommended Practices of the American Oil Chemists' Society, 4th Edn., AOCS Press, Champaign (1995).

11. R.M. SILVERSTEIN, G.C. BASSLER and T.C. MORILL, Spectrometric Identification of Organic Compounds, 5th edn., John Wiley \& Son, New York, pp. 122-124 (1991).

12. R. AWANG and S. AHMAD, Proceeding of 2001 International Palm Oil Congress-Oleochemicals conferences, Malaysian Palm Oil Board, Bangi, Kuala Lumpur, Malaysia, pp. 90-96 (2001).

13. K.D. CARLSON, R. KLEIMAN and M.O. BAGBY, Epoxidation of Lesquerella and Limnanthes (Meadowfoam) Oils, J. Am. Oil Chem. Soc., Vol. 71, 175-182 (1994).

14. S.J. KIM, Cosmetic Raw Material Analysis and Quality, Vol. 1Hydrocarbons, Glycerides, Waxes and other Esters (Hilda Buttler, ed.), Micelle Press, Weymouth, England, pp. 33-52 (1994).

15. Irritection ${ }^{\circledR}$ Assay System Instruction Manual, In Vitro International, Irvine, CA, pp. 1-11 (1996).

16. R. AWANG, S. AHMAD, Y.B. KANG and R. ISMAIL, Characterization of Dihydroxystearic Acid from Palm Oleic Acid, $J$. Am. Oil Chem. Soc., Vol. 78, 1249-1252 (2001). 